Creative Commons User License: CC BY-NC-ND

Abstracted by: EBSCOhost, Electronic Journals Service (EJS),

Google Scholar, Journal Seek, Scientific Commons,

Food and Agricultural Organization (FAO), CABI and Scopus
Journal of Agricultural Extension

Vol. 25 (4) October, 2021

ISSN(e): 24086851; ISSN(Print); 1119944X

http://journal.aesonnigeria.org

http://www.ajol.info/index.php/jae

Email: editorinchief@aesonnigeria.org

\title{
Adoption of Banana (Musa spp) Production Technology among Small- Scale Farmers in Embu West Sub-County, Kenya
}

https://dx.doi.org/10.4314/jae.v25i4.12

\section{Kathuri, Dominic Nthukuri}

Department of Agricultural Economics and Extension

University of Embu,

Email: dominickathuri@gmail.com, Phone No: +254711986709

\section{Ndirangu, Samuel Njiri}

Department of Agricultural Economics and Extension

University of Embu,

Email: ndirangu.samuel@embuni.ac.ke, Phone No: +254 723987104

\section{Gichimu, Bernard}

Department of Agricultural Resource Management

University of Embu

Email:wacikubm@gmail.com,

\begin{abstract}
The study examined adoption of recommended banana production technology among small-scale farmers in Embu West Sub-County, Kenya. Data were obtained from a sample of 384 small-scale banana farmers that were proportionately selected from four wards of the study area. A structured interview schedule was used for data collection. Both percentages and inferential statistics were employed in data analysis. The study used a logarithmic multiple linear regression model based on Cobb-Douglas production function. The amount of credit accessed, cost of the banana plantlets, fertilizer and manure had significant effects on banana output area. In addition, adoption of tissue culture banana, use of irrigation, debudding, desuckering, deleafing and banana value addition had positive and significant effects on banana production. The County government to enhance sensitization of small-scale banana farmers on the importance of adopting these and other recommended technologies for improved banana yields.
\end{abstract}

Keywords: Banana adoption, recommended banana technologies, production

\section{Introduction}

Banana (Musa spp.) is an important fruit crop in the world and is cultivated over an area of more than four million hectares, with an annual production of more than seventy million tons (Pappu, Patil, Jain, Mahindrakar, Haque, \& Thakur, 2016). It is the third most important starchy staple food after cassava and sweet potato (Food Agricultural Organization Statistics, 2018). In Kenya, banana is mainly grown and managed by smallholder farmers, predominantly peasant women (Paul, Harding, Tushemereirwe, \& Dale, 2018). It contributes to about 32 percent of the foreign income of the total exported fruits (Horticultural Crop Directorate, 2016). Bananas are produced mainly in Western, Central, and parts of Eastern 
Creative Commons User License: CC BY-NC-ND

Abstracted by: EBSCOhost, Electronic Journals Service (EJS), Google Scholar, Journal Seek, Scientific Commons,

Food and Agricultural Organization (FAO), CABI and Scopus
Journal of Agricultural Extension

Vol. 25 (4) October, 2021

ISSN(e): 24086851; ISSN(Print); 1119944X

http://journal.aesonnigeria.org

http://www.ajol.info/index.php/iae

Email: editorinchief@aesonnigeria.org

regions (Thuo, 2018). These regions have a high potential for banana production due to their agro-ecological characteristics, which greatly support the growth of banana crops. Bananas are mainly consumed domestically, with an annual per capita consumption of $220-460 \mathrm{Kg}$, providing more than 25percent of the total calories consumed (FAOSTAT, 2018). Despite the importance of the crop and availability of suitable producing areas, Kenya has been experiencing low banana production as a result of pests and diseases, poor agronomic practices, and low access to clean and affordable planting materials (Wahome, Maingi, Ombori, Kimiti, \& Njeru, 2021).

According to Wahome et al. (2021), the most important factors affecting banana production are labour and performance of agronomic management practices which include the use of quality planting materials, appropriate use of fertilizers, mulch and manure. One of the main recommended technologies is the use of tissue culture bananas whose adoption is less than $7 \%$ in Kenya and significantly lower in Uganda and Burundi (Warinda, Nyariki, Wambua, Muasya, \& Hanjra, 2020). A recent impact study for Kenya showed positive yield effects of tissue culture banana adoption but also pointed out the importance of good extension and proper plantation management (Murongo, Wangai, Mwine, \& Ayuke, 2018). Tissue culture banana plantlets require appropriate handling and management practices to optimize their benefits. Consequently, this additional requirement and the relatively high cost of tissue culture bananas plantlets (US\$1.20 - 2.00) pose an extra adoption challenge to the Kenyan farmers (Wahome et al., 2021).

Soil fertility management through proper use of organic and inorganic fertilizers is another recommended technology as it results to improved banana production. A study by Muthee, Gichimu \& Nthakanio (2019) established that the best fertilization regime should be based on a leaf or soil analysis which provides a guide on exact applications for particular soils and management conditions from year to year. The recommended average rates of nutrients applications for tropical bananas are: $400-600 \mathrm{~kg} / \mathrm{ha} / \mathrm{year}$ of Nitrogen $(\mathrm{N}), 200-300 \mathrm{~kg} / \mathrm{ha} / \mathrm{year}$ of Phosphorous ( $\left.\mathrm{P}_{2} \mathrm{O}_{5}\right), 850-1100 \mathrm{~kg} / \mathrm{ha} /$ year of Potassium $(\mathrm{K})$ and 2 tones/ha/year of lime/dolomite (Muthee et al., 2019). These relatively high fertilizer rates are necessary because high-yielding banana crops extract large quantities of nutrients from the soil. Consequently, fertilizer application in banana orchards would improve soil fertility and hence increase production. However, Muthee et al., (2019) noted that application of inorganic fertilizers is not common among banana farmers in Embu County.

Apart from fertility management, other recommended practices including pest and disease control, weeding, irrigation, desuckering, deleafing and debudding (removal of the male bud) should also be given adequate emphasis to enable farmers to achieve stable yield levels (Warinda et al., 2020). However, according to Muthee et al. (2019) very few banana farmers in Embu County have adopted these banana management practices. Pests and diseases pose a substantial problem to sustainable banana production in East and Central Africa, with a 
Creative Commons User License: CC BY-NC-ND

Abstracted by: EBSCOhost, Electronic Journals Service (EJS), Google Scholar, Journal Seek, Scientific Commons,

Food and Agricultural Organization (FAO), CABI and Scopus
Journal of Agricultural Extension

Vol. 25 (4) October, 2021

ISSN(e): 24086851; ISSN(Print); 1119944X

http://journal.aesonnigeria.org

http://www.ajol.info/index.php/iae

Email: editorinchief@aesonnigeria.org

significant risk to destabilize food security and household income in the region. The key diseases and pests include banana xanthomonas wilt (BXW) disease, yellow and black sigatoka disease, Fusarium wilt, banana weevil and nematodes (Tinzaara, Stoian, Ocimati, Kikulwe, Otieno \& Blomme, 2018). Bananas should consistently receive $200 \mathrm{~mm}$ to $220 \mathrm{~mm}$ of water per month (Muthee et al., 2019). Failure to practice irrigation implies that moisture stress affects the yields. Weeds compete with bananas for water and nutrients thus reducing yields. In addition, certain weeds found in banana orchards harbor pests and diseases that cause major losses in production (Tinzaara et al., 2018).

Desuckering refers to removal of surplus and unwanted suckers from banana stool which would otherwise compete with the main plant for water and nutrients and reduce production level (Bizikova et al., 2020). On the other hand, deleafing and debudding are recommended banana technologies in management of some banana diseases. Debudding should be done 3 weeks after flowering to prevent the insect vector from transmitting the BXW disease (Nakakawa, Mugisha, Shaw Tinzaara \& Karamura, 2017). Deleafing is the sanitary removal of leaves, or parts of them, that are infected with black leaf streak disease (BLSD). It increases the efficiency of fungicide applications and has been shown to reduce premature ripening. However, it involves a trade-off between the removal of infected leaves and the preservation of a minimum leaf surface area to ensure an adequate development of the bunch until harvest (Muthee et al., 2019).

Value addition is one of the recommended postharvest practices for perishable horticultural products as it guarantees higher returns and comes with an opportunity to open new markets as well as extending farmers marketing seasons (Schiassi, Lago Souza, Santos Meles, Resende \& Queiroz, 2018). Some of the challenges that small-scale banana farmers face is fluctuating prices due to overproduction and lack of storage facilities for ripe bananas (Obaga and Mwaura, 2018). Value addition can therefore be termed as the process of enhancing the production and profit level of a product. There are several products that can be made from bananas including wine, flour, yoghurt and crisps which are by-products once the bananas have been processed. This study therefore evaluated the adoption of recommended banana production technologies among small-scale farmers in Embu West Sub-County.

\section{Methodology}

The study was conducted in Embu West Sub-County of Embu County, Kenya. The sub-county was considered for this study because of its high production of bananas. The sub-county has an area of $88.7 \mathrm{~km}^{2}$ with a population of 127,100 (Kenya National Bureau of Statistics, 2019). The sub-county lies between latitude $0^{\circ} 8^{\prime}$ and $0^{\circ} 50^{\prime}$ 'South and longitude of $37^{\circ} 3^{\prime}$ and $37^{\circ} 9^{\prime}$ 'East. The temperatures in the area range between $20^{\circ} \mathrm{C}$ and $30^{\circ} \mathrm{C}$ with rainfall ranging from $640 \mathrm{~mm}$ to as high as $1495 \mathrm{~mm}$ per annum (Government of Kenya, 2018). The long rains occur between March and June while the short rains fall between October to December. The main cash crops grown in the area are tea and coffee. The main 
Creative Commons User License: CC BY-NC-ND

Abstracted by: EBSCOhost, Electronic Journals Service (EJS),

Google Scholar, Journal Seek, Scientific Commons,

Food and Agricultural Organization (FAO), CABI and Scopus
Journal of Agricultural Extension

Vol. 25 (4) October, 2021

ISSN(e): 24086851; ISSN(Print); 1119944X

http://journal.aesonnigeria.org

http://www.ajol.info/index.php/jae

Email: editorinchief@aesonnigeria.org

food crops grown include banana, maize, sorghum, cassava and millet. Dairy keeping is also substantially practiced in the area.

The target population of this study was 13,793 banana farming households in four wards of Embu West sub-county. The study employed two stage stratified sampling procedure in which first, Embu West sub-county was selected based on high banana production. The second stage involved selecting the major four banana producing wards namely; Gaturi South, Mbeti North, Kithimu and Kirimari (Table 1). Banana farming households were then randomly selected from each ward to form a sample size of 384 banana farming households. The sample size was selected using the formula of Cochran (1963) as shown in equation 1.

$\mathrm{n}=\frac{\mathrm{z}^{\mathrm{p}} \mathrm{pq}}{\mathrm{d}^{\mathrm{z}}}$

Where: $\quad \mathrm{n}=$ desired sample size;

$Z$ = standard normal deviate at 95 percent (1.96) confidence level;

$\mathrm{p}=$ the estimated proportion of the target population having the characteristics being measured (0.5);

$q=1-p(1-0.5) ;$ and

$\mathrm{d}=$ level of statistical significance $(0.05)$

Therefore: $\mathrm{n}=(1.96)^{2}(0.5)(0.5) /(0.05)^{2}=384$ banana farming households.

Probability proportionate to size technique was used to determine the number of banana farming households to be interviewed in each ward. In this case, the total number of banana farming households in each ward was divided by the total number of banana farming households in the four wards then multiplied by the sample size as shown in equation 2.

$M=\frac{n}{N} * 384$

Where $M$ is the number of banana farming households to be interviewed; $n$ is the number of banana-farming households in each ward; and $N$ is the total number of banana-farming households in the four wards (Ministry of Agriculture Livestock and Fisheries, 2018).

Table 1: Summary of banana farming households interviewed in each ward Ward Total number of households Sampled respondents sampled

\begin{tabular}{lcc}
\hline Gaturi South & 3750 & 104 \\
Mbeti North & 593 & 17 \\
Kithimu & 9000 & 251 \\
Kirimari & 450 & 12 \\
\hline Totals & 13,793 & 384 \\
\hline
\end{tabular}

\section{Model Specification}

The study used a production model to examine the effect of inputs and recommended technologies on banana production. The production model expresses a functional relationship between quantities of inputs used and quantity of banana 
Creative Commons User License: CC BY-NC-ND

Abstracted by: EBSCOhost, Electronic Journals Service (EJS),

Google Scholar, Journal Seek, Scientific Commons,

Food and Agricultural Organization (FAO), CABI and Scopus
Journal of Agricultural Extension

Vol. 25 (4) October, 2021

ISSN(e): 24086851; ISSN(Print); 1119944X

http://journal.aesonnigeria.org

http://www.ajol.info/index.php/jae

Email: editorinchief@aesonnigeria.org

produced at different levels of technology adoption. The production function also describes the extent at which output changes with variation in inputs during a specified period of time (Daniel and Afofum, 2019). A logarithmic linear model based on Cobb-Douglas production function was applied in this study to express this production relationship as well as show the effect of adoption of the recommended technologies on banana production. This model most suited for this study because it provides parameters that are easy to interpret and estimate. The model was specified as shown in equation 3

$\ln Y=\ln \beta_{0}+\beta_{1} \ln X_{1}+\beta_{2} \ln X_{2} \ldots+\beta_{m} \ln X_{m}+\alpha_{1} z_{1}+\cdots \alpha_{1} z_{m}+\varepsilon$

Where: $Y$ is the banana yield per acre;

$\beta_{0}$ is the vertical intercept;

$\beta_{1}$ to $\beta_{n}$ are the inputs co-efficient of the regressor or multiplier that describes the size of the effect the inputs have on the dependent variable $Y$;

$\alpha_{1}$ is the coefficient for the banana recommended technologies;

$X_{1}$ to $X_{m}$ are quantities of inputs used;

$z_{1}$ to $z_{n}$ are the selected banana recommended technologies;

$\ln$ is natural logarithm; and

$\varepsilon$ is the composite error term.

\section{Results and Discussion}

\section{Characteristics of Banana Production among the Smallholder Farmers}

Table 2 shows that the mean size of land allocated to banana production was 2 acres. The small farm sizes were attributed to land fragmentation resulting from the ever-swelling population growth in the study area (Murimi, Njeru, Gichimu \& Ndirangu (2019). The results further showed that majority of the respondents engaged about 80 man-days per year in banana production. The respondents apportioned a range of KES 15,000 to 80,000 of credit per year in banana production which averaged KES 30,000 per year. The yields per acre per year ranged from $2500-10,000 \mathrm{Kgs}$ which averaged 6,500 Kgs. The income per acre ranged from KES 25,000 to 180,000 which averaged KES 80,000 . The farmers maintained an average of 4 suckers per stool with a minimum of 2 and a maximum of 7 suckers per stool (Table 2).

\section{Table 2: Characteristics of banana production among small-scale farmers}

\begin{tabular}{lcccc}
\hline Variable & Minimum & Maximum & Mean & $\boldsymbol{\sigma}$ \\
\hline Farm size (acres) & 0.5 & 3 & 2 & 1.265 \\
Labour (Man-days /year) & 30 & 120 & 80 & 26 \\
Credit (KES/ year) & 15000 & 80000 & 30000 & 3500 \\
Yield/acre (Kg) & 2500 & 10000 & 6500 & 1250 \\
Income/Acre (KES) & 25000 & 180000 & 80000 & 4036 \\
Suckers per stool & 3 & 7 & 4 & 2.76 \\
\hline
\end{tabular}

$\sigma=$ Standard Deviation; IKES $=110$ US Dollars 
Creative Commons User License: CC BY-NC-ND

Abstracted by: EBSCOhost, Electronic Journals Service (EJS),

Google Scholar, Journal Seek, Scientific Commons,

Food and Agricultural Organization (FAO), CABI and Scopus
Journal of Agricultural Extension

Vol. 25 (4) October, 2021

ISSN(e): 24086851; ISSN(Print); 1119944X

http://journal.aesonnigeria.org

http://www.ajol.info/index.php/iae

Email: editorinchief@aesonnigeria.org

\section{The Effect of Input Application on Banana Production}

The effects of different input related factors on banana production were analysed using multiple regression and the results are presented in Table 3 . From the results, the model results had a positive and significant constant coefficient denoting that the model selection was fit to carry out the analysis. In addition, the coefficient of multiple determination was 0.826 denoting that approximately $83 \%$ of the variation in banana output per acre was explained by the independent variables included in the model. The remaining $17 \%$ was accounted for by the error term and variables not considered in the model. The F-value of 90.34 was positive and significant at $1 \%$ level signifying that most of the variables in the model explained the variation of banana output per acre. The return to scale of 1.062 indicated that there was a potential of increasing the gross income by increasing input use. This was an indication that the small-scale banana farmers had not optimally utilized their inputs in banana production and were at the initial stage of the production function.

The coefficient of amount of credit obtained by farmers for banana farming activities was 0.3764 and was significant at $5 \%$ level. This implied that access to credit increased banana production by $38 \%$. Apparently, access to credit increases the financial muscle of the farmers to access inputs, equipment, hired labour and adopt recommended technologies thus increasing banana production. Similar observation was made by Mohammed, Aziz, \& Ogunbado, (2016) and Udoka, Mbat, \& Duke, (2016) who concluded that access to farm credits was among the essential factors needed for enhanced agricultural production among the small-scale farmers.

On the other hand, the cost of tissue culture banana plantlets had a negative coefficient $(-0.3578)$ that was significant at $1 \%$ level. This implied that increasing the cost of banana plantlets would reduce the amount output by a factor of 0.36 . Similar observation was made by Tumuhimbise \& Talengera, (2018) who concluded that the high cost of tissue culture banana plantlets deprived farmers the capacity to adopt improved banana varieties thus contributing to reduced yields.

Fertilizer and manure application recorded positive coefficients of 0.3467 and 0.6534 that were significant at $5 \%$ and $1 \%$ respectively. This implied that proper adoption of fertilizer and manure application would increase banana production by a factor of 0.35 and 0.65 respectively. Fertilizer and manure application improves soil fertility which in turn improves banana output in terms of quality and quantity of the produce (Meya, Ndakidemi, Mtei, Swennen, \& Merckx, (2020). According to Gichimu, Muthee \& Nthakanio, (2020), banana production has a high requirement of macro and micro nutrients especially nitrogen, phosphorous, potassium, calcium, magnesium and sulphur. Fertility enhancement through addition of organic and inorganic fertilizers is necessary because banana crops extract large quantities of nutrients 
Creative Commons User License: CC BY-NC-ND

Abstracted by: EBSCOhost, Electronic Journals Service (EJS),

Google Scholar, Journal Seek, Scientific Commons,

Food and Agricultural Organization (FAO), CABI and Scopus
Journal of Agricultural Extension

Vol. 25 (4) October, 2021

ISSN(e): 24086851; ISSN(Print); 1119944X

http://journal.aesonnigeria.org

http://www.ajol.info/index.php/jae

Email: editorinchief@aesonnigeria.org

Table 3: Effect of inputs used on banana production

\begin{tabular}{|c|c|c|c|c|c|}
\hline Variable & Parameter & Coefficient & SE & $\mathbf{z}$ & $\mathbf{P}>/ \mathbf{z} \mid$ \\
\hline Constant & $\beta_{0}$ & 6.3244 & 0.5023 & 10.56 & $0.000^{\star \star \star}$ \\
\hline Labour (Man-day) & $\beta_{2}$ & 0.5623 & 0.1318 & 0.52 & 0.479 \\
\hline Farm size (acres) & $\beta_{3}$ & 0.8104 & 0.0501 & 1.62 & 0.126 \\
\hline Amount of credit (KES) & $\beta_{4}$ & 0.3764 & 0.1463 & 2.57 & $0.010^{\star *}$ \\
\hline Cost of plantlets (KES) & $\beta_{5}$ & -0.3578 & 0.0890 & -3.78 & $0.000^{\star \star *}$ \\
\hline Fertilizer (Kgs) & $\beta_{6}$ & 0.3467 & 0.7650 & 1.43 & $0.036^{\star \star}$ \\
\hline Manure (Kgs) & $\beta_{7}$ & 0.6534 & 0.4573 & 2.67 & $0.000^{\star \star *}$ \\
\hline $\begin{array}{c}\mathrm{R}^{2} \\
\text { Return to scale } \\
\text { F-value }\end{array}$ & & $\begin{array}{l}826 \\
062 \\
.34^{\star \star \star}\end{array}$ & & & \\
\hline
\end{tabular}

Adoption of the Selected Banana Recommended Technologies on Production

Results in Table 4 indicate that, adoption of tissue culture had a positive coefficient of 0.5694 that was significant at $1 \%$ level indicating that adoption of the technology increased banana production per acre by $57 \%$. These results are in line with Wanyana, Murongo, Mwine, \& Wamani, (2019) that the adoption of banana tissue culture technology increased the banana production among the small-scale farmers in Uganda. Planting tissue culture banana plantlets gives the farmers a good start because the seedlings are pest and disease free. It also enables farmers to adopt improved banana varieties that are high yielding hence increasing the amount of output obtained. Adoption of various irrigation systems by banana farmers was also found to increase banana production. The positive coefficient of adoption of irrigation was 0.1120 and was significant at $5 \%$. This implied that adoption of irrigation in banana farming increased banana production by $11.2 \%$. Water is very crucial in banana farming as it facilitates the growth as well as the ripening of banana fruits thus increasing the yield and farmers' income. According to Panigrahi, Thompson, Zubelzu \& Knox, (2021) practicing irrigation in banana production is one of the easiest ways of managing the water stress thus improving production during dry periods.

The practice of debudding had a positive and significant (1\%) influence on banana production with a coefficient of 0.2143 . This implied that adoption of debudding as a recommended technology increased banana production by $21.43 \%$. According to Nakakawa et al. (2017), debudding is a good practice because it helps to prevent banana diseases such as xanthomonas wilt. The study further demonstrated that desuckering which involves reduction of suckers per stool had a positive influence on banana production at $5 \%$ level of significance indicating that increased adoption of desuckering increased banana production by $20.5 \%$. Muthee et al. (2019) also reported that desuckering resulted in a significant increase in banana yields among small-scale farmers in Embu County. Similarly, deleafing which involves the removal of excess leaves from banana plants was found to have a significant effect on the yields. The practice recorded a positive coefficient of 0.2919 which was significant at $1 \%$ level implying that its adoption increased production per unit area by $29.2 \%$. 
Creative Commons User License: CC BY-NC-ND

Abstracted by: EBSCOhost, Electronic Journals Service (EJS),

Google Scholar, Journal Seek, Scientific Commons,

Food and Agricultural Organization (FAO), CABI and Scopus
Journal of Agricultural Extension

Vol. 25 (4) October, 2021

ISSN(e): 24086851; ISSN(Print); 1119944X

http://journal.aesonnigeria.org

http://www.ajol.info/index.php/jae

Email: editorinchief@aesonnigeria.org

Muthee et al. (2019) noted that deleafing reduces the incidences of pests and diseases thus increasing the yields. Other cultural practices such as mattacking, mulching and pest and disease control had no significant influence on banana production in the study area.

At postharvest level, adoption of various banana value addition practices was found to have a significant $(p \leq 0.05)$ influence on banana production. Value addition is the process of converting a product from its original form to a more valuable form that is convenient to the user or consumer (Musyoka, Isaboke, \& Ndirangu, 2020). The results indicated that adoption of banana value addition increased banana production by $9.44 \%$. These results were in agreement with Obaga and Mwaura (2018) that adoption of banana value addition helps in boosting the farmers' income. The small-scale farmers in the study area were found to have embraced various value addition practices including banana ripening, making banana flour and crisps, hence increasing their farming income.

Table 4: Effects of technology adoption on banana production

\begin{tabular}{lllll}
\hline Variables & Coefficient & Std Error & t-value & VIF \\
\hline Tissue culture & 0.5694 & 0.1362 & $2.715^{\star \star *}$ & 1.546 \\
Irrigation & 0.1120 & 0.0098 & $1.223^{\star *}$ & 1.092 \\
Debudding & 0.2143 & 0.0022 & 6.757 & 1.153 \\
Desuckering & 0.2050 & 0.0065 & 1.443 & 1.062 \\
Deleafing & 0.2919 & 0.1121 & 2.604 & 1.667 \\
Mattacking & 0.0391 & 0.0949 & 0.413 & 1.036 \\
Mulching & 0.0686 & 0.0365 & 1.4154 & 1.084 \\
Pest and disease control & -0.1741 & 0.1974 & -0.882 & 2.689 \\
Banana value addition & 0.0944 & 0.0504 & 1.874 & 2.702 \\
\hline
\end{tabular}

${ }^{* * *} P \leq 0.01,{ }^{* *} P \leq 0.05$

\section{Conclusions and Recommendations}

This study established that access to credit has a high potential of increasing banana production in the study area due to enhanced capacity of the farmers to access vital agricultural resources. Adoption of tissue culture bananas had a significant positive effect on banana production among small-scale farmers in Embu-West Sub-County. However, the cost of tissue culture plantlets was the major hindrance to the adoption of this technology. Other recommended technologies whose adoption was found to promote banana production in the area included irrigation, debudding, desuckering, deleafing and banana value addition. The county government in collaboration with ministry of agriculture to enhance sensitization of small-scale banana farmers on the importance of adopting these and other recommended technologies for improved banana yields per unit area. 
Creative Commons User License: CC BY-NC-ND

Abstracted by: EBSCOhost, Electronic Journals Service (EJS), Google Scholar, Journal Seek, Scientific Commons,

Food and Agricultural Organization (FAO), CABI and Scopus
Journal of Agricultural Extension

Vol. 25 (4) October, 2021

ISSN(e): 24086851; ISSN(Print); 1119944X

http://journal.aesonnigeria.org

http://www.ajol.info/index.php/iae

Email: editorinchief@aesonnigeria.org

\section{References}

Bizikova, L., Nkonya, E., Minah, M., Hanisch, M., Turaga, R. M. R., Speranza, C. I., ... \& Timmers, B. (2020). A scoping review of the contributions of farmers' organizations to smallholder agriculture. Nature Food, 1(10), pp.620-630

Daniel, E. J., \& Afofum, A. A. (2019). Econometric analysis of efficiency of rice inputs-output relationship in Yobe State. International Journal of Innovative Finance and Economics Research, 7(4), pp. 101-109.

Food and Agricultural Organization Statistics (FAOSTAT) (2018). Food and agricultural organization of the United Nations, Rome, Italy.

Gichimu, B.M., Muthee A.I. and Nthakanio P.N. (2020). Agronomic benefits of Shubhodaya-mycorrhizal bio-fertilizer on banana production in Embu County, Kenya. Journal of Agronomy, 19 (2), pp. 65-75.

Government of Kenya (2018). Kenya National Bureau of Statistics (KNBS). Statistical Abstract, 2018, Nairobi.

Horticultural Crop Directorate (2016). Validation report 2016-2017. Retrieved from http://horticulture.agricultureauthority.go.ke on $2^{\text {nd }}$ July 2021.

Kenya National Bureau of Statistics (2019). Economic survey; The 2019 Kenya Population and Housing Census. Government printers, Nairobi, Kenya.

Meya, A., A Ndakidemi, P., Mtei, K. M., Swennen, R., \& Merckx, R. (2020). Optimizing soil fertility management strategies to enhance banana production in volcanic soils of the Northern Highlands, Tanzania. Agronomy, 10(2), pp.289-296.

Ministry of Agriculture Livestock and Fisheries (2018). Climate risk profile Embu. Kenya county climatic risk profile series: The Kenya ministry of agriculture, livestock and fisheries, Nairobi, Kenya.

Mohammed, A. I., Aziz, A. B., \& Ogunbado, A. F. (2016). The influence of murabahah finance on the relationship between farm credit and agricultural output in Nigeria: a proposed framework. Asian Journal of Multidisciplinary Studies, 4(12), pp.93-97.

Muthee, A.I., Gichimu B.M. and Nthakanio P.N. (2019). Analysis of banana production practices and constraints in Embu County, Kenya. Asian J. Agric. Rural Dev. 9(1), pp.123-132.

Murimi E.K., Njeru L.K., Gichimu B.M. and Ndirangu S.N. (2019). Effects of urban expansion on agricultural resources: A case study of Embu Town in Kenya. Asian Journal of Agricultural Extension, Economics \& Sociology 33(4), pp.1-11.

Murongo, M., Wangai, K. J., Mwine, T. J., \& Ayuke, O. F. (2018). Farmer-based dynamics in tissue culture banana technology adoption: a socio-economic perspective among small holder farmers in Uganda. African Journal of Agricultural Research 13 (50), pp. 28362854.

Musyoka, J. K., Isaboke, H. N., \& Ndirangu, S. N. (2020). Farm-level value addition among small-scale mango farmers in Machakos County, Kenya. Journal of Agricultural Extension, 24(3), pp.85-97.

Nakakawa J., Mugisha J.Y.T., Shaw M.W., Tinzaara W. and Karamura E. (2017). Banana xanthomonas wilt infection: The role of debudding and roguing as control options within a mixed cultivar plantation. International Journal of Mathematics and Mathematical Sciences pp. 2-13

Obaga, B.R. \& Mwaura, F.O. (2018). Impact of farmers' participation in banana value addition in household welfare in Kisii Central Sub-County. International Academic Journal of Social Sciences and Education, 2(1), pp.25-46.

Panigrahi, N., Thompson, A. J., Zubelzu, S., \& Knox, J. W. (2021). Identifying opportunities to improve management of water stress in banana production. Scientia Horticulturae, 276, pp.36-50 
Creative Commons User License: CC BY-NC-ND

Abstracted by: EBSCOhost, Electronic Journals Service (EJS), Google Scholar, Journal Seek, Scientific Commons,

Food and Agricultural Organization (FAO), CABI and Scopus
Journal of Agricultural Extension

Vol. 25 (4) October, 2021

ISSN(e): 24086851; ISSN(Print); 1119944X

http://journal.aesonnigeria.org

http://www.ajol.info/index.php/jae

Email: editorinchief@aesonnigeria.org

Pappu, A., Patil, V., Jain, S., Mahindrakar, A., Haque, R., \& Thakur, V. K. (2016). Advances in industrial prospective of cellulosic macromolecules enriched banana bio-fibre resources. International Journal of Biological Macromolecules, 79, pp .449458.

Paul, J. Y., Harding, R., Tushemereirwe, W., \& Dale, J. (2018). Banana21: from gene discovery to deregulated golden bananas. Frontiers in plant science, 9, pp.558-565.

Schiassi, M. C. E. V., Lago, A. M. T., de Souza, V. R., dos Santos Meles, J., de Resende. V., \& Queiroz, F. (2018). Mixed fruit juices from Cerrado. British Food Journal 120 (2), pp.2334-2348.

Tinzaara, W., Stoian, D., Ocimati, W., Kikulwe, E., Otieno, G., \& Blomme, G. (2018). Challenges and opportunities for smallholders in banana value chains. Achieving sustainable cultivation of bananas, 1, pp.1-26.

Thuo, C. N. (2018). An assessment of adoption of tissue culture bananas in the semi-arid areas of lower Eastern region of Kenya (Doctoral dissertation).

Tumuhimbise, R., \& Talengera, D. (2018). Improved propagation techniques to enhance the productivity of banana (Musa spp.). Open Agriculture, 3(1), pp.138-145.

Udoka, C. O., Mbat, D. O., \& Duke, S. B. (2016). The effect of commercial banks' credit on agricultural production in Nigeria. Journal of Finance and Accounting, 4(1), pp.1-10.

Wahome, C. N., Maingi, J. M., Ombori, O., Kimiti, J. M., \& Njeru, E. M. (2021). Banana production trends, cultivar diversity, and tissue culture technologies uptake in Kenya. International Journal of Agronomy, 20 (3) pp.1234-1247.

Wanyana, B., Murongo, M. F., Mwine, J., \& Wamani, S. (2019). Agro-related policy awareness and their influence in adoption of new agricultural technologies; A case of tissue culture banana in Uganda. African Journal of Agricultural Research 13 (50), pp. 2945-2960.

Warinda, E., Nyariki, D. M., Wambua, S., Muasya, R. M., \& Hanjra, M. A. (2020, February). Sustainable development in East Africa: impact evaluation of regional agricultural development projects in Burundi, Kenya, Rwanda, Tanzania, and Uganda. In Natural Resources Forum 44 (1), pp.3-39. 